\title{
A ROTA DO MOSA E AS RELAÇÕES LONGÍN- QUAS DAS REGIÕES MOSANAS ENTRE OS SÉCULOS VIII e XI (*).
}

Estas notas - que são antes interrogações lançadas pelo historiador ao arqueólogo do que considerações definitivas permitirão, talvez, relacionar alguns problemas da arte do Mosa pelo denominador comum da via de comunicação: estrada comercial, guerreira; religiosa, por onde, ao mesmo tempo que homens, mercadorias e moedas, passaram idéias, técnicas, fórmulas arquitetônicas e repertórios decorativos.

Como, com efeito, sem um estudo geográfico, cronológico e econômico das vias de comunicação propor corretamente a questão das origens da arte do Mosa, da independência e da anterioridade das obras saídas dos ateliers do Mosa em relação às regiões vizinhas do Mosela e do Reno, que formam, juntamente com a região do Mosa, aquilo que se poderia chamar o complexo histórico, econômico e artístico lotaríngio? Como identificar a contribuição das tradições locais e das influências exteriores, próximas ou longínqüas, que deram à arte do Mosa a sua sensibilidade particular, sem situar a região do Mosa na rêde de relações gerais que a prende - e quão fortemente, como veremos! - ao restante do mundo medieval? Como fazer tudo isso sem mostrar a importância da posição geográfica que dá às regiões do Mosa a virtude da receptividade e a fôrça do raciocínio: limitada pelo oeste com a França ocidental, Reims e Saint-Denis e a leste com as regiões renanas, os confins germano-eslavos e, mais longe ainda, mas nessa mesma direção, além das fronteiras germânicas e da imensidade do mundo eslavo, já nos fins das regiões florestais da Europa central e oriental, com as possantes civilizações de Bizâncio e do Oriente muçulmano; limitada, pelo norte, com a desembocadura do delta do Reno-Mosa no Mar do Norte, as Ilhas Britânicas e as vias marítimas ou fluviais que levam, elas tam-

(*). - Tradução gentilmente autorizada pelo autor de artigo estampado em L'Art Mosan. Journées d'études. Paris. 1953 (Bibliothèque Générale de l'École Pratique des Huates Études, VIe Section), pp. 1-28. (Tradução de E. Simôes 
bém, ao Império bizantino e ao mundo muçulmano, e, ao sul, com o leque de caminhos para a França meridional, a Espanha, a Itália e, finalmente, o Mediterrâneo bizantino e muçulmano?

Conservação das tradições antigas, romanas e gaulesas além da Gália romana; influências bárbaras nos trabalhos de madeira e metal; chegada de influências longínqüas - processos técnicos e esquemas decorativos - influências do Oriente bizantino e do mundo muçulmano; depois, difusão das formas particulares assim elaboradas para a Inglatterra, para os ateliers de estatuária e de alvenaria; para a Boêmia e Polônia... Recepção depois difusão: num e noutro momento, as vias de comunicação são as mesmas, gravadas na natureza e na história. Mas, as correntes que as percorrem são mais ou menos intensas, seu fluxo - homens, coisas e idéias - aumenta ou diminui segundo o deslocamento dos centros motores da economia e da civilização.

Ora, o período que se estende do século VIII ao XI e que corresponde às primeiras obras-primas e ao início da expansão da arte do Mosa, representa para o Ocidente um momento capital, o do despertar: despertar econômico e urbano, renovação da cultura material e da civilização. Sob a influência do apêlo vindo das ricas metrópoles do mundò muçulmano em pleno desenvolvimento, o comércio exterior do Ocidente bárbaro mudou de direção e de papel: de importador passa a exportador, e, de passivo, a ativo. O ouro que fugia para o Oriente para pagar as mercadorias preciosas, sêdas, marfins, especiarias... que importavam os mercadores levantinos, os syri, aflui agora para o Ocidente para comprar os escravos, as armas, as peles... que os mercadores ocidentais e nórdicos, os judeus do Império carolíngio, os italianos, os anglo-saxões, os escandinavos, exportavam para o mundo muçulmano (1).

Essa reviravolta comercial, essa profunda transformação na estrutura das trocas implicam num incremento das relações longínqüas e na organização de uma vasta rêde de vias de comunicação por onde vão circular largamente as influências as mais diversas: carolíngias, bizantinas, muçulmanas, que irão continuar o "internacionalismo" da primeira arte romana. E não é sem importância notar, logo de início, que tôdas essas vias de comunicação - estradas de comércio e de civilização - têm sua confluência na região do Mosa.

(1). - Cf. Mahomet et Charlemagne, le problème économique, "Annales $\mathrm{E}$. S. C.", t. III, 1948, pp. 188-199. 


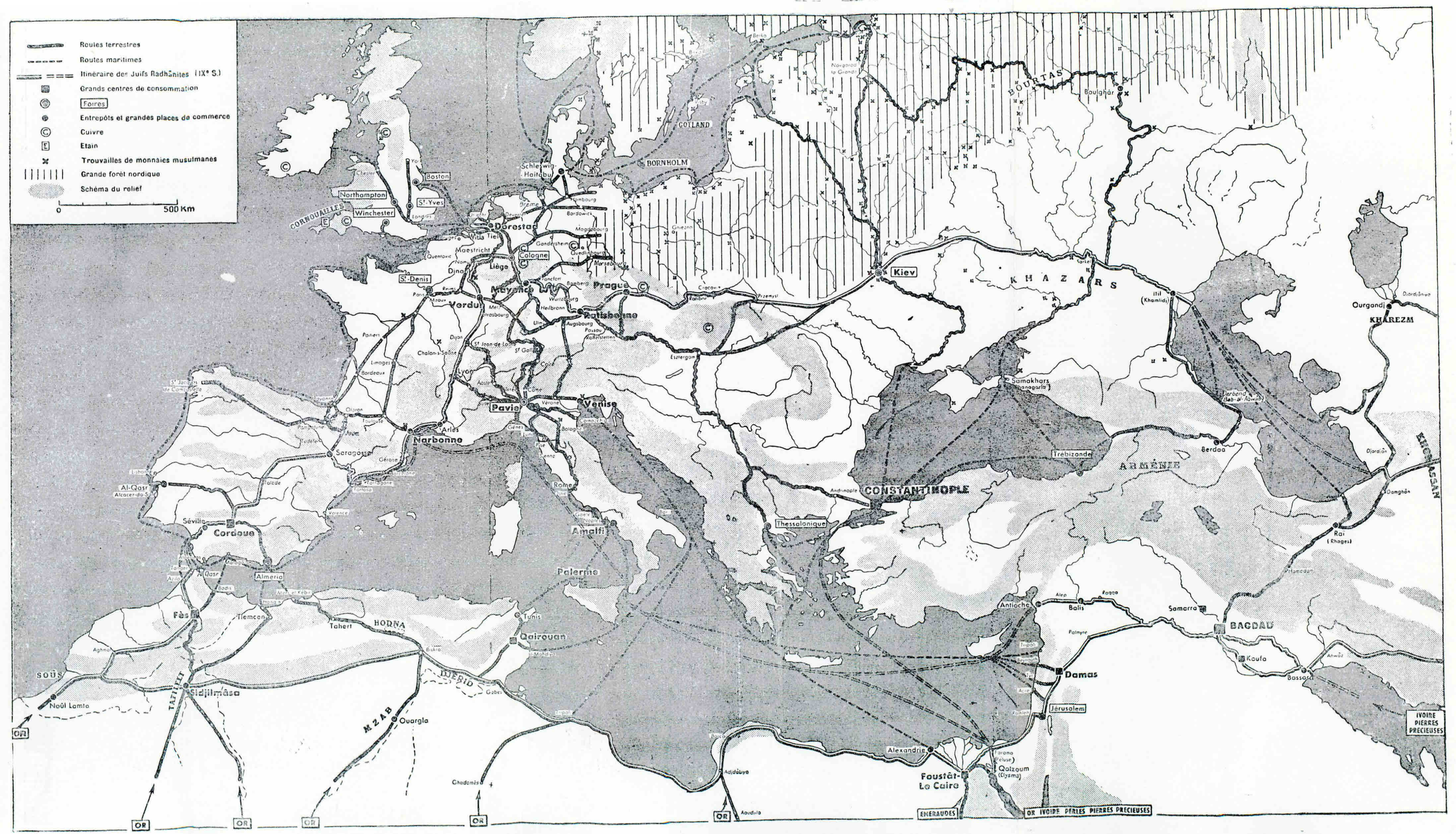


Uma carta esquemática das grandes correntes de circula"ção entre os séculos VIII e XI (2) mostra imediatamente uma larga faixa de relações gerais, em forma de anel, cercando e começando a desbordar - a Europa central e ocidental, em grande parte ainda perdida no meio das brumas das suas florestas pantanosas e da sua economia primitiva. Pelo Mediterrâneo, pelo Atlântico, pelos mares nórdicos, pela região dos rios russos, do Cáspio e do Mar Negro, começa a se desenhar uma verdadeira rêde de vias de comunicação - marítimas ou fluviais, ligadas por vias terrestres - que têm os seus centros motores em Bagdá, Bizâncio, Egito e Espanha muçulmanos, dado o apêlo emitido pelas suas grandes cidades em contínuo progresso, pelas necessidades das suas civilizações suntuosas e também pelo desenvolvimento das suas técnicas e pelo poder de compra que lhes empresta a posse de quase todo o ouro do mundo (3).

Desta visão de conjunto, os geógrafos da Idade Média muçulmana tinham plena consciência. Um persa anônimo do século $X o$ indica quando nota que

"Baritâniya (as Ilhas Britânicas) é o empório de Roû́m (Constantinopla e, em geral, o Império bizantino) e de Andâloûs (A Espanha muçulmana)" (4) .

O historiador Mas'oûdî a esboça quando descreve as rotas usadas pelo comércio de peles preciosas de raposa negra desde as zonas de caça da região dos bourtâs à confluência do Volga e do Oka, onde, mais tarde, vão se instalar as célebres feiras de pele de Nijni-Novgorod:

"Da região dos bourtâs são exportadas peles de raposa negra, a mais procurada e a mais rara de tôdas as peles. A raposa negra é o luxo dos príncipes dêsses povos não-árabes. Estas peles se destinam às regiões de Bâb alabwâd (Derbend, no Cáspio) e de Berdaa (na Armênia) e também a outras regióes, tais como Khorâssan e Kharezm (na Ásia Central, ao sul do mar de Aral), onde elas

(2). - Indicamos, uma vez por tôdas, a carta geográfica anexa a êste tnabalho.

(3). - Cf. L'or musulman du VIIe au XIe siècle, "Annales -E. S. C.", t. II, 1947, pp. 143-160.

(4). - Houdoud al-âlam (As Fronteiras do mundo), ed. W. Barthold, Leningrado, 1930, trad. V. Minorsky, Londres, 1937 ("Gibb Memorial N. S.", t. XI), p. 158. 
são trabalhadas. Elas também são exportadas para os paises do norte, os países eslavos, porque os bourtâs são vizinhos próximos dêsses países nórdicos. De lá clas são levada ao país dos francos, à Espanha Muçulmana e a todo o Maghreb" (5).

Os dois extremos dessas vias de comunicação, Saragossa no Ebro e Gourgandj no braço do Amou-Daria, que se lançava então no Cáspio, são indicados pelos viajantes árabes como os grandes centros de tratamento das peles nórdicas no mundo muçulmano. Dessas duas cidades manufatureiras, ricos casacos, gorros ou regalos de pele eram distribuídos pelas grandes cidades muçulmanas do Oriente e do Ocidente: Bagdá, Foustât-Cairo ou Córdova. São as mesmas vias que se dirigem para este e para oeste, em direção aos mesmos territórios de caça - a imensa floresta russa - percorridas pelas levas de escravos sagâlîbâ (escravos) destinados aos corpos de guarda e aos haréns dos palácios muçulmanos. Itil, na embocadura do Volga, e Verdun, nas margens do Mosa, são os grandes entrepostos e ao mesmo tempo centros de concentração, de castração e de redistribuição para o comércio mundial dos escravos destinados aos países do. Islão (6). Os mesmos caminhos, portanto, que seguiram, desde o século IX, os mercadores de armas ocidentais exportadas para os mercados muçulmanos, seja pela via do norte (Báltico e rios russos), seja pela via do sul (Mediterrâneo ocidental e portos do Levante), as famosas espadas de "Firandjâ" (a França e o Império Carolíngio), forjadas entre o Sena e o Reno e escoadas pelo vale do Mosa, os portos do delta Reno-Mosa ao norte, ou a cabeça da linha de Verdun ao sul; fer flamingr das Sagas ou "aço de Verdun", que cantava ao ser manobrado.

Peles nórdicas, escravos eslavos, espadas francesas formam o grosso das mercadorias que as cidades comerciantes da Itália - Veneza, Amalfi, Gaeta (7) — e os judeus râdhânites (rodanianos) do Sul da França exportavam para os mer-

(5). - Mas'oudi, Kitâb at-tanbih wa'l-ishâf (Livro da Observação e da Revisão), ed. M. J., de Goeje, Leyde, Bibliotheca Geographorum Arablcornm, t. VIII, p. 62 e trad. Carra de Vaux, Paris, 1897, pp. 90-91.

(6). - A respeito do comércio de escravos eslavos destinados ao mundo muculmano, cf. entre outros: Ibn Khordadhbeh (BGA, VI), pp. 92 e 103-104; Ibbn Al-Faqih (BGA, V), pp. 82-84 e 270; Ibn Hawqal (BGA, II), pp. 70-76; Mouqaddasi (BGA, III), p. 242; Agobard (MGH, Epist. III), pp. 183 e 185; Liudprando, Antapodosis (MGH, ss, III), p. 156. Cf. também Infra.

(7). - Cf. as Honorantie civitatis Papie, publ. pon A. Solmi, L'amministrazione finanziaria nel regno italico nell'alto medio, Bolletino della Società Pavese di Storia Patria", t. XXXI, 1931, pp. 20 e seg. 
cados do Oriente muçulmano. Os itinerários dêstes mercadores judeus, rotas marítimas de Narbona até a Síria, ou continentais, passando pela Espanha, Maghreb e Egito, onde o mesopotânio Ibn Khordâdhbeh (8) exerceu um cargo de chefia do Império abássida nos meados do século IX, representam o segmento - o segmento meridional — da zona circular de relações a longa distância que, então, encerrava a Europa. As numerosas descobertas de moedas muçulmanas feitas ao longo dos rios russos, nas margens do Báltico e do Mar do Norte, e, mesmo, na Islândia, indicam o segmento setentrional (9). Por elas passaram, junto com os dirhems abássidas e samânidas, os cauries do Oceano fndico encontrados nos arredores de Visby, nas tumbas da época dos vikings (10), um sistema de pêsos copiado da Pérsia pelo mundo escandinavo (11), e, talvez também, as influências que, provenientes das cidades ao redor de Bagdá, a abássida e de Boukhara, a samânida, deveriam desabrochar nos estabelecimentos do plano circular, recentemente descobertos na Dinamarca (12). No outro sentido caminharam os mercadores Roûs (13) (russos: eslavos ou escandinavos), transportando peles e armas ou arrebanhando escravos destinados aos grandes centros urbanos de Khorâssan, de Kharezm ou do Iraque. As fontes árabes nô-los mostram descendo os rios russos, traficando em Boulghâr, perto da confluência do Volga e do Kama, germem da futura Kazan, dizendo preces aos seus ídolos de madeira, em busca de frutuosas relações comerciais, ou incinerando o corpo de um dos seus chefes no seu barco, entre as suas mulheres, imoladas sôbre o seu cadáver (14). Em Itil, capital dos khazars, terminava sua navegação fluvial. Lá êles pagavam ao soberano uma taxa de trânsito sôbre as suas mercadorias, depois atravessavam o Cás-

\footnotetext{
(8). - Kitâb al-Masâlik wa'l-Mamálk (Livro dos caminhos e dos reinos), ed. e trad. de Goeje (BGA, VI), pp. 114-116.

(9). - Cf. A. Markoof, Topografia Kladof vostotchnykh Monet, São Petersburgo, Academia Imperial de Ciências, 1910. Acrescentar os complementos dados por R. Vasmer, depois de 1927, nos Trudy Numizmatcheskoj Komisij e os Beiträge zur Kunde Estlands.

(10). -Cf. A. Bugge, Die Wikinger, 1896, p. 247.

(11). - T. J. Arne, Ein persische Gewichtssystem in Schweden, "Orientalisches Archiv", t. II, 3, 1911.

(12). - Cf. a nota de H. P. L'Orange, nos studies dedicated to D. M. Robinson, t. I, Londres, 1951.

(13). - Transcrição árabe do têrmo Rnotsi (eslavo ou escandinavo).

(14). - Comparar esta nota hist6rica com os numerosos "barcos de incineraçāo" normandos, descobertos nas costas do Mar do Norte e da Mancha. Cf. P. Le Chatellier e B. Le Pontois, La Barque de l'ile de Groix, "Bulletin de la soc. archéol. du Finistère", t. XXXV, 1908.
} 
pio e continuavam sua viagem sôbre o dorso dos camelos até Bagdá, onde os eunucos eslavos lhes serviam de intérpretes (15). Além das metrópoles do Oriente muçulmano, o outro principal ponto de destino dos mercadores Rhos (16) era o Império bizantino e o "Mar Romano" (O Mediterrâneo); em Constantinopla um bairro - o do São Mammas - lhes estava reservado e o Basileus cobrava antecipadamente uma taxa de entrada sôbre as mercadorias. Chegavam de Kouyâba (Kiev), pelo Dnieper e retornavam por Samakhars "a cidade dos judeus" (Tmutarakan, Phanagoria no estreito de Kertch) (17). De Kiev, a rota continuava para o norte por um dos afluentes do Dnieper superior, depois pelo curso do Lovat, o lago Ilmen, em Novgorod-a-grande atingia o domínio marítimo escandinavo do Báltico: êste era o "Caminho dos Varegues aos Gregos" dos primeiros cronistas russos (18).

Através da floresta e da estepe da Europa oriental, a rota dos rios russos para o Cáspio e o Mar Negro punham em contacto as coisas nórdicas com as orientais e mediterrâneas. $\mathrm{Pa}$ ra o oeste, pelo Atlântico, as Ilhas Britânicas, a península ibérica e pelo estreito de Gibraltar o domínio do norte se comunicava com o do Mediterrâneo. As navegações pelo "Oceano Tenebroso" dos Ocidentais, "o Mar Envolvente" dos geógrafos árabes - se perderam seu cronista depois de Festus Avienụs e sua obra Ora Marítima (19) - não cessaram nunca durante tôda a alta Idade Média, mesmo depois da conquista da Espanha pelos muçulmanos. Jamais as relações entre os portos da Bretanha, da Irlanda, da Armórica, do Gôlfo de Gasconha e os portos muçulmanos, da costa lusitana, do Algarve e do estuário do Guadalquivir: al-oûsh-boûna (Lisboa), al-Qasr Abî Dânis (Alcácer do Sal), Ishbiliya (Sevilha), cessaram. Algumas noticias recebidas da literatura geográfica árabe (20) ou dos cronistas latinos (21), provam êste intercâmbio e indicam a chegada, por esta via, de peles, escravos e armas de estanho (22), oriundos da ilha da Bretanha. A partir do século

(15). - Ibn Khordadhbeh, loc. cit., pp. 115-116.

(16). - Transcrição grega de Ruotsi.

(17). - Ibn Khordadhbeh, loc. cit., p. 115; Ibn Al-Faqih, loc. cit., p. 270.

(18). - Crônica de Nestor, trad. de L. Léger, Paris, 1884, pp. 16 e seguintes.

(19). - Cl: A. Berthelot, Festus Avienus: Ora Maritima, Paris, 1934.

(20). - Cf. por exemplo: Houdoud al-âlam, p. 158; Maqqari, Analectes, ed. Dozy, Dugat, Krehl e Wright, Leyde, 1855-1861, I, pp. 121-122.

(21). - Cf., por exemplo, a Vita S. Philtberti, ed. R. Poupardin, p. 66 e os Mira.cula S. Philiberti, MGH, SS, XV, p. 303 .

(22). - 0 estanho no mundo muçulmano tem dois nomes que indicam as suas duas grandes regiōes de produção: qasdîr (Cassiteros), o estanho "ocidental" vindo da Cornualha e qalari (de Malaca), o estanho "orlental", 
IX, os normandos - os madjoûs dos autores árabes - deveriam, nas suas expedições de comércio e de pirataria ao longo das costas atlânticas, tomar o mesmo caminho, atacar os grandes portos de emirato de Córdova (23), e, franqueando o estreito, estender-se pelo Mediterrâneo. Foi a um dos seus chefes, residente em uma das ilhas dinamarquesas que o emir omíada de Córdova, Abd ar-Rahman II (822-852) enviou seu poeta cortesão, al-Ghazal (24), como embaixador. Era esta rota do Atlântico que seguiam, no século XI, os navios dos peregrinos inglêses que se destinavam a Santiago-de-Compostela ou a Jerusalém (25) e a frota de Winnemer de Bolonha, levando socorros a Balduino de Bolonha, fundeou em Tarso, quando da 1a. cruzada (26). Não nos esqueçamos que o Monge de Saint-Gall, escrevendo no fim do século IX, menciona em um pôrto da Narbonense, a presença de navios "bretões" (quer dizer inglêses) ao lado de barcos de negociantes judeus e de navios de piratas normandos (27).

Assim o circuito - comércio, pirataria, trocas de todos os gêneros - se fecha: Báltico, rios da Europa oriental, Cáspio ou Mar Negro, Mediterrâneo, Oceano Atlântico, Mancha, Mar do Norte, Báltico. Leva em consideração êsse traçado, o duplo ataque conjugado, lançado em 859-860 pelos normandos de Rurik e de Hasting contra Constantinopla pelas rotas comerciais dos rios russos e do Mar Negro, de um lado, e pelas do Atlântico e do Mediterrâneo, do outro.

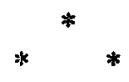

vindo da Malásia. O Egito era o limite da influência dos dois centros, já que recebia o estanho oriental melo Oceano índico e portos do Mar Vermelho e o estanho ocidental por Alexandria. No século XIII ainda, o geógrafo Ibn Sa'id, em Abou'L-Fida, Taqwîn al-bouldân, Geographia, II, 1, p. 307, descreve a rota do estanho desde a Grã.Bretanha até Alexandria pelo Atlântico, o Garona, Toulouse e Narbona. Cf. o itinerário dado por Diodoro de Sicília $(V, 28)$ no 1.0 século a. C.

(23). - A respeito das expedições normandas contra a Espanha muçulmana, cf. R. Dozy, Recherches sur l'histoire et la littérature des Arabes d'Espagne, 3a. ed. Leyde 1881, II $_{j}$ pp. 250-371 e E. Lévi-Provençal, in Enciclopédia do Isłāo, III, pp. 105-106, S. verbo "Madjûs".

(24). - A. Fabricius, Lambassade d'al-Ghazal auprès du roi des Normands. "Atas do VIII Congresso Internacional de Orientalistas", Estocolmo e Cristiana, 1889, vol. II.

(25). - Ainda no século XIII: ilha de Wight, Galícia (Santiago de Compostela), Sevilha, Cádiz, estreito de Gibraltar, Ceuta, Barcelona, Toulon, Antibes, Nice, Civitavecchia, Messina, Creta, São João D’Acre, Eimonis Chronicon, MGH, SS, XXIII, pp. 478 ss.

(26) : - De Sturler, Les relations politiques au Moyen-Åge et les échanges commerclaux entre le duché de Brabant et l'Angleterre, 1936, p. 71.

(27). - MGH, SS., t. II, p. 757. 
Sôbre esta vasta corrente de circulação anular que envolve a Europa da Alta Idade Média, feixes de estradas que se ramificam convergem para a região do Mosa. O Mosa médio toma assim, numa carta geográfica, o aspecto de um centro onde terminam ou se cruzam os principais itinerários comerciais provenientes do Mar do Norte, da Bacia parisiense e dos Países renanos, do domínio mediterrâneo (França do Sul, Espanha e Itália) e das regiões da Europa central e oriental. Por causa dessas vias de comunicação que ligavam a região do Mosa às longínqüas e pujantes civilizações do Oriente bizantino e muçulmano, essa região desempenhou, entre os séculos VIII e IX, um papel que poderíamos chamar de mundial, antes de cèder o pôsto, já no decorrer do século XII, às cidades flamengas do oeste e às cidades hanseáticas do leste.

O delta comum ao Reno, Mosa e Escalda, pela sua rêde de braços e de ilhas baixas dá acesso fácil ao Mar do Norte e à costa oposta: o estuário do Tâmisa. Para Londres (antiga Londinium; no século VIII: Lunvenwic, um centro comercial, ou Lundenburgo, uma praça-forte) convergem dois velhos caminhos: a Watlinga Straete, vinda do noroeste, de Chester (antiga Legiones castrum e a Ermida straete, do Nordeste, de York (antiga Eboracum) e de Lincoln (antiga Lindum Colonia). Estas estradas, entre os séculos IX e XI, servem para o escoamento dos produtos de várias regiões econômicas importantes, onde se localizam grandes mercados: Winchester, Boston, Northampton, Saint-Yves. Por meio do comércio anglosaxão e, sobretudo do frisão (28), ativas trocas tèm lugar entre os portos da costa inglêsa e os do delta do Reno-Mosa: Deventer, sôbre o Ijssel, Utrechet, na confluência do Wecht e do Vieux-Rhin, Dorestad principalmente (29), na confluência do Vieux-Rhin e do Leck, Tiel, sôbre o Waal, Witla, sôbre o Mosa, depois Antuérpia sôbre o Escalda e Bruges sôbre o Zwyn. Todos êsses centros não existiram ao mesmo tempo como grandes entrepostos comerciais: êles foram se sucedendo no tempo, mas o acesso ao mar sempre foi mantido pelas regiões interio-

(28). - Nos séculos VIII e IX, os frisões estão espalhados por tôda a Europa do noroeste: em Londres e em Mogúncia, nas feiras de Salnt-Denis e nas feitorias do Báltico. Para os transportes marítimos, êles já utilizavam - famoso coque (casco de navio) que, mais tarde, seria imitado pelos hanseáticos.

(29). - Atualmente Vijk bij Duurstede. De 750 a 850, mais ou menos, Dorestad foi o entreposto central do grande comércio frisão. $E^{\prime}$ o vicus nominatissimus famosus dos Anais do século IX. Foi suplantado, no século $X$, como centro comercial mais importante, por Tiel. Cf. J. H. Holwerda, Dorestad en onze vroegste Middeleeuren, Leyde, 1929. 
res do Reno, Mosa e Escalda. Por êles passaram o estanho e o cobre da Inglaterra, trabalhados pelos fundidores e serralheiros de Liège, Huy ou de Dinant, os escravos anglo-saxões e celtas destinados ao grande centro de redistribuição de Verdun, e; sem dúvida, também as trocas culturais e artísticas que ligam tão fortemente, nos séculos X e XI, a escola do Mosa e da Inglaterra (30) .

Em Maestricht (o antigo Trajectum ald Mosam), o Mosa rera transposto pela velha estrada romana de Reims à Colônia, por Bavai e Tongres; em Verdun, pela de Reims à Estrasburgo, por Metz, com entroncamento para Mogúncia e Coblença, por 'Treves. Itinerário usado durante tôda a Alta Idade Média (31). Ao norte como ao sul da floresta das Ardenas, a região do Mosa médio abria, de um lado, sôbre a Bacia parisiense e, de outro, sôbre a fachada renana. As relações entre o grupo de miniaturistas de Reims e o do Mosa, da mesma forma que entre os ourives do Mosa e os de Saint-Denis já foram assinaladas. Quanto ao complexo "reno-mosano", ainda é objeto de pesquisas e discussões apaixonadas (32): o estudo preciso da geografia e da cronologia da rêde de estradas dessas regiões dará ao problema de anterioridade e de influências uma base mais sólida e, certamente, mais objetiva. Pela estrada de Colônia e pelo portus de Maestricht, muito freqüentada pelos mercadores (33), as indústrias de Dinant e de Huy recebiam uma parte do cobre com que trabalhavam; vários documentos dos séculos XI e XII (34) mencionam compras de matéria-prima pelos dinanteses e huteses no mercado de Colônia e trans Rhenum, quer dizer, na Saxe, nas minas do Harz. Pelo caminho de Mogúncia, Verdun via afluir às suas prisões grandes levas de escravos capturados nos confins germano-eslavos do Saale e do Meno (35). Estas levas se juntavam aos escravos anglo-saxões transportados pelo Mar do Norte e baixo Mosa e aos prisioneiros eslavos capturados nas margens do Elba inferior e que vinham

(30). - P. Francastel, Le problème mosan, in "L'histoire de l'art, instrument de la propagande germanique", 1945, pp. 100 e ss. F. Masai, Essal sur les origines de la miniature dite irlandaise, Bruxelas, 1947.

(31). - Como o indicam as mudanças dos soberanos merovínglos e carolíngios.

(32). - Cf. a preciosa colocação do problema por F. Francastel, ob. cit., pp. 78-105.

(33). - Portus negociatorum multitudine frequentissimus, Eginhard, Translatio et Miracula S. Marcellini et Petri, MGH, SS, XV, p. 261.

(34). - Citados e comentados por H. Pirenne, Histoire de la constitution de la ville de Dinant au moyen-âge; reeditado in "Les villes et les institutions urbaines", t. II, pp. 72-73.

₹35). - Vita Sturmi, GMH, SS, II, p. 369. Cf. Ch. Verlinden, L'esclavage dans le monde ibérique médiéval ("Anuario d'História del derecho español", t. XII, 1935, pp. 365-424). 
ao Mosa pela Saxe, Turíngia e Colônia ou Coblença (36). Os mercadores judeus de Verdun transformavam-nos em eunucos e, depois, os vendiam nos mercados do emirato de Córdova, conseguindo com êsse tráfico "grandes lucros" (37). A localização nos muros de Verdun (38) dêste importante tráfico de escravos era devida à importância da posição da velha fortaleza do Mosa, localizada onde terminava a navegação fácil dos. grandes barcos e se processava uma baldeação de cargas e também onde se cruzavam a grande estrada comercial norte-sul e a oeste-este que, através dos desfiladeiros da Argone e de. Woèvre ligava a bacia parisiense com o vale do Reno.

De Verdun à Espanha muçulmana, nos séculos VIII e IX, o itinerário principal, seguia pelos campos do Saona e do Ródano. Um trajeto terrestre, pelo alto vale do Mosa, Langres. e Dijon conduzia os mercadores ou os embaixadores (39) aos. primeiros portus do Saona, onde retomavam a via fluvial. Segundo as épocas, os portos de embarque mais freqüentados. foram Auxone, Saint-Jean de Losne ou Chalon-sur-Saône. Até Lião, o Saona, de curso lento e calmo permitia uma navegação repousante. Mas, em Lião, para poder afrontar o Ródano, rápido e tumultuoso, uma nova baldeação era necessária. Uma rica e influente comunidade judaica demonstrava a importância da estação de baldeação de Lião na rota para Espanha. Estes judeus, com suas riquezas e seu tráfico de escravos é que, na primeira metade do século IX, seriam acusados por Agobardo, bispo de Lião de raptar crianças cristãs e de juntá-las às levas de escravos pagãos destinados aos mercados espanhóis (40). O trajeto fluvial terminava em Arles,

(36). - Tarifa de entrada de Coblença, Hansisches Urkundenbuch, III, p. 388 .

(37). - Immensum Iucrum, Liudprando, Antapodosis, MGH, SS, III, p. 156 . Cf. Maqqari, Analectes, ed. de Leyde, $I$, p. 92, citando o escritor do $X$ século, Ibrâhîm al-Qarawi (ar-Raqîq): "Os francos são vizinhos dos eslavos. Eles aprisionam êstes na guerra $e$ os vendem em Espanha, freqüentemente. Os escravos são castrados pelos judeus que vivem sob a proteção dos francos e que habitam o Império franco e os territórios muculmanos vizinhos. Esses castrados são exportados da Espanha para todos os outros países do mundo muçulmano..." Desde o século IX, os virdunenses mercatores são notados nas estradas da Espanha, Miracula. S. Bertini, AA., SS., BB., set. 11, p. 597. Cf. F. Rousseau, La Meuse et le pays mosan en Belgique, Namur, 1930, pp. 72 e ss.

(38). - Ou, melhor, no cinturão dos bairros comerciais, o mercatorum claustrum,. do outro lado do Mosa, a que a ligava duas pontes, Richer, Historiae, MGH, SS, III, p. 629 .

(39). - Missão de Jean de Gorze para Otão $10^{\circ}$ na cốrte de Córdova, em 953, guiado pelos verduneses: Vita Johanni abbatis Gorziensis, MGH $_{11}$ SS, IV, p. 370-371.

(40). - Agobardo, MGH, Epist., III, pp. 138 e 185. 
onde os barcos do Ródano eram trocados pelos navios marítimos: Arles que o missus Teodulfo, bispo de Orleans, nos descrevia em 798, como um mercado onde afluiam as pérolas da India, os tecidos de ouro orientais, os couros de Córdova e os dinares muçulmanos (41). Aqui, como em Verdum e em Lião, um bairro habitado por uma grande colônia judaica cuidava dos armazéns para as mercadorias e das prisões para os escravos, que aguardavam, uns e outros, o seu re-embarque para Narbona (42), o grande pôrto que, em movimento, sobrepujava o de Arles e também centro de uma numerosa coletividade judaica (43) que negociava com os portos do Levante muçulmano e com os da Espanha: Barcelona, "onde os judeus eram mais numerosos do que os cristãos", Tarragona "dos judeus" (44) e, daí, para as costas muçulmanas, Tortosa, Valença, Almeria (45), onde as comunidades judaicas eram importantes. A estreita ligação que existia entre os judeus de Narbona, de Barcelona e de Tortosa, de um lado e do outro da fronteira entre a Cristandade e o Islão, encontra ilustração na anedota contada pelo Rawd al-mi'tar (46): em 456 da Hégira (1054-1055), o conde de Barcelona desejando raptar a mulher de uma importante personagem de Narbona, se dirige ao senhor muçulmano de Tortosa, antigo escravo eslavo Nabîl (um dêsses aventureiros que se tornaram donos de uma cidade, quando da decomposcição do Califado de Córdova), que imagina um estratagema e, "por intermédio dos seus judeus e dos seus correspondentes em Narbona, levam a cabo a tarefa".

A partir de Arles, entretanto, nem todo tráfico para a Espanha seguia a via marítima: uma estrada passava por Narbona, cortava as últimas encostas dos Pirineus orientais no desfiladeiro de Perthus e, por Gerona e Barcelona, alcançava Tarragona, Tortosa e o vale do Ebro.

\footnotetext{
(41). - "Iste gravi numero nummos fert divitis auri "Quos Arabum sermo sive caracter arat..." "Versus contra judices", MGH, Poet., 1, p. 498.

(42). - Era de Narbona que partiam os mercadores judeus râdhânitas que se destinavam ao Egito e à Síria, segundo descreve Ibn Khordâdhbeh, sensivelmente contemporâneo de Agobardo. Cf. supra.

(43). - $O$ bispo de Liāo, Agobardo, loc. cit., dirige uma carta de viva crítica ao bispo de Narbona, Nibrido, que vivia em bons têrmos com os judeus, recebla-os em sua mesa, tolerava uma confraternização qüotidiana entre cristãos e judeus.

(44). - Idrisi, Description de l'Afrique et de l'Espagne, ed. e trad. R. Dozy e M. J. de Goeje, texto p. 191; trad. p. 231.

(45). - Almeria: a cidade das foires de Aumarie, das nossas canções de gesta.

(46). - Ed. e trad. E.-Lévi-Provençal. Leyde, 1938, p. 54.
} 
A esta primeira grande estrada das regiões do Mosa à Espanha, que faz reviver uma direção romana, uma outra, que aparece no século $X$, vem se juntar - e talvez fôsse melhor dizer reaparece por que se trata realmente do renascimento de uma direção ainda mais antiga: a direção neolítica que atravessava obliqquamente o território gaulês, desde o Reno, em direção aos vales do Sena, do Loire, do Garona, até as fraldas dos Pirineus ocidentais (Somport, Roncevaux, Vélate). Êste renascimento, sem dúvida, está relacionado com a invenção das relíquias de Santiago na Galícia e com a organização progressiva da peregrinação rumo à Compostela (47). Nos séculos X e XI podemos reconstituir os itinerários seguidos pelos mercadores, pelos peregrinos, pelos correios monásticos, desde a região do Meuse, de Maestricht ou de Verdun à Reims, Meaux e Paris, depois, por Orleans, Poitiers, Blaye e Bordéus, Bayonne, o desfiladeiro de Velate e Pampeluna ou Ostbat, Saint-Jean-Pied-de-Port, Roncesvales e Pampeluna, ou, ainda, Oloron, o Somport, Jaca e Saragossa (48). Em Poitiers, uma ramificação dessa grande estrada levava a Limoges e Toulouse, de onde se podia, indiferentemente, alcançar os passos dos Pirineus ocidentais ou orientais. Uma dessas estradas é que foi seguida pelos negotiatores virdunenses in divitiis potentissimi, os negociantes, desta vez cristãos que, voltando da Espanha e passando por Meaux, se apoderaram, graças à cumplicidade de um clérigo, das relíquias de São Saintin, antigo bispo de Verdun, que morreu em Meaux e cujo corpo era venerado na igreja dessa cidade (49). Também foi uma dessas estradas que, em 1050 - mas partindo da Catalunha - tomaram os mensageiros portadores do rôlo funerário que comunicava a morte do conde Guifred II de Cerdanha, irmão de Oliva, abade de Santa Maria de Ripoll e de São Miguel de Cuxa, às igrejas e monastérios amigos do outro lado do Pirineus: vale do Garona, vale do Loire, vale do Sena, vale do Mosa e, por Maestricht e Aix-la-Chapelle, o vale o Reno; a volta se efetuando pelas casas religiosas da Borgonha e do vale do Róda-

(47). - Cf. L. Vazquez de Parga, J. Ma. Lacarra e J. Uria Riu, Las peregrinaciones a Santiago de Compostela, Madrí, 1947-1949. Y. Renouard, Le pèlerinage à Saint-Jacques-de-Compostelle et son importance dans le monde médieval, in "Revue Historique", 1951.

(48). - Segundo um ritmo que foi muito bem estudado por M. Elie Lambert. Cf. seu artigo sôbre Roncevaux, in "Bulletin hispanique" 1935, pp. 417-436.

(49). - Translatio Sancti Santini, in Calmet, Histoire de Lorraine, $I$, p. 28 e in abade $D$. Clouet, Histoire de Verdun et du pays verdunois, Verdun, 18671870, I, p. 286 e Ir, p. 30, nota 1. 
no (50). Um importante documento do século XI, uma tarifa aduaneira de Jaca e Pampeluna (51) nos indica quais as mercadorias que passavam por estas estradas dos Pirineus: produtos do Norte (metais, armas, peles, tecidos de Flandres) em troca de produtos do mundo muçulmano (moedas de ouro, tecidos de brocado de sêda, tinturas, especiarias) e do Império bizantino (púrpuras de Constantinopla).

Estradas do Ródano e da Aquitânia abrindo às regiões do Mosa e do Reno todo o horizonte da Espanha muçulmana: econômico, intelectual, artístico. Uma moeda do Imperador Henrique II (1002-1024) copia, no reverso, o dinar do califa de Córdova Hishâm al-Mouayyad billâh (976-1013) (52). No século $\mathrm{X}$, a religiosa Hroswitha, do fundo da sua abadia saxônica de Gandersheim, celebra os esplendores e as delícias de Córdova (53). As ciências "árabes" penetram na Lotaríngia e vêem irrigar o centro de Liège (54). O mapa das influências mosárabes sofridas pela primeira arte romana, reproduz bastante exatamente o das vias de comunicação (55).

Tais itinerários ligavam as regiões do Mosa aos desfiladeiros dos Alpes, os Clusas dos documentos carolíngios (56): pelo Reno - que as estradas vindas do vale do Mosa alcançavam, nós o vimos, em Colônia, em Coblença, Mogúncia, ou Estrasburgo - até Coire, depois Ilanz (57), o Luckmanier e Bellinzona (58); ou ainda Septimer e Como; - pelas passagens do Jura (mais freqüentemente pelo desfiladeiro de Jougne),

(50). - L. Delisle, Boubaux funéraires, p. 49.

(51). - Publ. por J. Ma. Lacarna, Un arancel de aduanas del siglo XI, "Atas do I Congresso Internacional de Pireneistas", Saragosa, 1950. (Separata, pp. 19-20). O documento é datado do reino de Sancho Ramirez (1076-1094), mas faz alusão a uma situação anterior que nos leva à primeira parte do século XI.

(52). - J. Karabacek, Spanisch-arabisch-deutsche Nachprägungen für Rolen, "Numismatische Zeitschrift", I, 1869, pp. 135-148.

(53) . - Ed. Strecker, Teubner, p. 154.

(54). - J. W. Thompson, The introduction of Arabic Science into Lorraine in the tenth Century, "Isis", XII, 1929, pp. 184-194; M. C. Welborn, Lotharingia as a center of Arabic and scientific influence in the XIth century, ibid., t. XIV, 1931.

(55). - J. Puig e Gadafalch, Le premier art roman. Paris, 1928, mapas das pp. 127 e 134.

(56). - G.-G. Dept, Le mot clusas dans les diplômes carolingiens, in "Mélanges H. Pirenne", I, pp. 189-198.

(57). - Onde se encontrou um tesouro de moedas muculmanas, dirhems de prata e 2 dinares de ouro: um do califa aì-Mahdî do ano 166 da Hégira (782783) e outro do califa Haroûn ar-Râshid de 193 da Hégira (808-809). Cf. Neues Archiv, t. XXXII, 1908, p. 442 (interpretação de J. Karabcek dada por Luschin v. Ebengreuth).

(58). - Esta era a rota dos peregrinos dos Países-Baixos e das regiões renanas. Cf. Annales Stadenses. MGH, SS, XVI, pp. 335 e 339. 
São Maurício d'Agaune, o Grande São Bernardo e Aosta (59); pelo Saona, Lião, a Maurienne, o desfiladeiro de Cenis (60) e Susa (61). De Como, Bellinzona, Aosta ou Susa tôdas as estradas convergiam para Pavia, sôbre o Tessino, não longe da sua confluência com o Pó. Pela rêde fluvial da planície padana (62) e pelas estradas terrestres, principalmente por aquela que, por Bréscia, Verona e Pádua, alcançava Veneza, Pádua, dominava largamente o fundo do Adriático. A via francigena ou francisca descia de São Bernardo por Aosta, continuava depois de Pavia para Placência, onde atravessava o Pó, o desfiladeiro de Cisa nos Apeninos, Pontremoli, Luni e, por Siena, alcançava Roma (63).

A té o século XI, Pavia foi a capital do reino da Itália, onde os soberanos lombardos, depois carolíngios, depois germânicos, vinham cingir a corôa de ferro; ela foi assim, durante todo êsse período o grande mercado onde se trocavam os produtos do norte mediterrâneo e do Oriente pelos do Ocidente e do norte da Europa. Os textos a respeito das duas célebres feiras anuais (64) se escalonam do século IX ao XI (65): feiras que se estendiam às portas da cidade, numa grande planície próxima ao monastério de São Martinho, foris portam. Os mercadores se instalavam em tendas ou em lojas construídas de tijolos ou de pedras com cobertura de madeira, lojas que só eram ocupadas durante a feira. Aí, os mercadores de

(59). - Foi por Verceil, Ivrée e Aosta, a via francisca, que passaram os embaixadores enviados por Haroûn ar-Ráshid a Carlos Magno.

(60). - Que o viajante judeu do século XII, Benjamín de Tudela, chama "os desfiladeiros de Jean de Maurienne".

(61). - Sôbre os desfiladeiros dos Alpes durante a Idade Média. Cf. entre outros: E. Barelli, Le vie del commercio fra l'Italia e la Francia nel medio evo, "Bolletino Storico Subalpino", t. XII, pp. 60 e ss. K. Schrod, Reichsstrassen und Reischverwaltung in Königreich Italien, Stuttgart, 1931, Beiheft 25, zur Vierteljahrsschrift f. Soz. - und Wirtschaftsgeschichte, pp. 6-38.

(62). - A respeito da navegação do Pó, cf. A. Solmí, Le diete imperiali di Roncaglia e la navigazione del Po presso Piacenza, "Archivio storico per le prov. parmensi", N. S. t. XI, 1910, pp. 25 e ss.

(63). - Este foi o itinerário seguido por Sigerico, arcebispo de Contuária, em sua viagem pela Itália, 990-994. Cf. J. Jung, Das Itinerar des Erzbrischofs Sigeric von Canterbury, "Mittheilungen für oesterr. Gesch. Forschung", XXV, 1904, pp. 1-90.

(64). - Que se estendiam por 15 dias, a primeira a partir do domingo de Ramos (março-abril) e a segunda a partir do dia de São Martinho ((1 de novembro).

(65). - O monge de Saint-Gall (MGH, SS, II, p. 760) contando a anedota da caça de Carlos Magno nos arredores de Pavia. Jean Diacre, ed. Monticolo, Chronache veneziana antichissime, Roma, 1909, p. 178. Vita Geraldi comitis Aureliacensis, AA, SS, BB, Out., VI, p. 309. Cf. F. L. Ganshof. Note sur un passage de la vie de Saint-Géraud d'Aurillac, in "Mélanges Jorga", 1933, pp. 295-307 Liudprando, Antapodosis, MGH, SS, III, pp. 337 e 389 . Honorantie civitatis Papie, ed. A. Solmi, loc. cit. 
Veneza e das cidades marítimas do mar Tirreno: Amalfi, Salerno, Gaeta, se encontravam com os mercadores ultramontanos, anglo-saxões sobretudo. Estes últimos gozavam do privilégio de não pagar direitos de entrada nos portos aduaneiros situados nos começos das rotas alpinas, graças aos presentes que, obrigatòriamente, cada três anos ofereciam à côrte de Pavia (66): cinqüenta libras de prata fina, casacos de pele, armas de preço, cães de fila com correntes e coleiras de metal dourado, encrustadas de gemas (67). Metais (estanho, cobre, prata, ferro), armas, peles, lã e linho, escravos dos dois sexos (68): eis as mercadorias que traziam às feiras de Pavia os mercadores ultramontanos e que os de Veneza e de Amalfi se encarregavam, em seguida, de distribuir para os mercados de Bizâncio e, sobretudo, do Mediterrpneo muçulmano (69). Em troca, êles levavam de Pavia, as sêdas, o marfim, as especiarias que ali traziam os mercadores das cidades marítimas da Itália (70). Na ida e na volta êles passavam pela rota do Mosa.

Rathier de Verona, êste curioso personagem, que deixou tão preciosas anotações a respeito da sociedade da Itália do Norte nos meados do século $\mathrm{X}$, insiste sôbre o. caráter cosmopolita, a vida fervilhante, as relações intensas de uma cidade como Pavia, onde êle foi, uma vez, lançado ao cárcere. Sua vida simboliza as relações estreitas que uniam então as regiões do Mosa e a Itália do Norte, porta do Oriente grego e muçulmano: oblato, em 895, em Lobbes (71); bispo de Verona (66). - Velho acôrdo, de que Canuto-o-Grande, rel da Inglaterra e da Dinamarca, obtem a confirmação quando da sua viagem a Pavia e a Roma, por ocasiāo da coroação de Conrađo II, em 1027, para pôr fim às disputas entre os guardas aduaneiros italianos e os mercadores anglo-saxóes. Canuto aproveitou também a sua viagem pela Itália para se entender com Rodolfo III, rei de Borgonha senhor dos pedágios do vale do Ródano, do Jura e da vertente norte dos Alpes ocidentais: Rodolphus rex, qui maxime ipsarum clausurarum dominator, como dizia o próprio Canuto em uma carta publicada em Mansi, Conc. Coll, XIX, p. 499.

(67). - Honorantie civitatis Papie, ed. A. Solmi, p. 21. Um tesouro de moedas anglo-saxônicas foi encontrado em Roma, sob o Forum, com fivelas de cobre, incrustadas de prata (data do depósito: 944-946): trabalho inglês ou mosano?

(68). - Mercadores mencionados pelas Hon. civ. Pap., como pelas tarifas dos postos aduaneiros dos Alpes, cujas indicações completam as fornecidas pelos pedágios dos Pirineus. Cf. supra.

(69). - A respeito das relaçōes bastante estreitas que ligavam os portos comerciais da Itália, do Adriático e do Mar Tirreno do domínio muçulmano. Cf. J. Gay, L'Italie méridionale et l'Empire byžantin, Paris, 1904, passim.

(70). - Cf. as Hon. civ. Pap., pp. 21-22, que enumeram as taxas que, nas feiras de Pavia, deviam pagar os mercadores de Veneza, Amalfi, Salermo, Gaeta, e a Vie de Saint Géraud d'Aurillac, loc. cit., que indica as principais mercadorias orientais existentes nessas feiras.

(71). - Claustro sôbre o Somme, no Hainaut, ligado ao bispo de Liège em 889 . 
em 932; depôsto, aprisionado, fugitivo, êle se refugia no sul da França, depois na côrte de Otão I; está em Lobbes em 944; em um instante torna-se bispo de Liège, entre 953 e 956 ; novamente bispo de Verona, de 966 a 968; morreu em Namur em 974 (72) . O círculo de relações de um dos seus sucessores no episcopado de Liège, Notger (972-1008), estava todo impregnado de influências italianas, gregas e orientais (73).

Pela estrada de Estrasburgo e do vale de Kunzig, ou, mais diretamente, pela estrada de Mogúncia, as bacias do Meno e do Neckar (74) e os desfiladeiros que cortavam a encosta calcária do Jura suavo, as regiões do Mosa se comunicavam com o vale do Danúbio e com as portas ảo mundo eslavo da Boêmia e da Polônia: Ratisbona e Passau, bispados missionários e cidades caravaneiras de onde partiam as lentas carretas (75) dos ruzanii, os mercadores judeus que comerciavam com os países da Europa oriental (76). De Ratisbona, pelo vale do Regen, para o passo de Domazlice aberto através das solitárias florestas da Sumava (o Boehmer Wald), o vale do Berounka e Praga. De Passau, Raffelstetten (77) ou Linz para o de Budejovice (Budweis), o alto vale do Vetava e Praga. O viajante judeu espa-

(72). - Um resumo da sua movimentada carreira em H. Pirenne, Histoire de Belgique, I, pp. 67-161 e 438 .

(78). - G. Kurth, Notger de Liège et la civilisation du siècle $x$, Paris, 1905. Notger fêz vir a Liège, como professor de grego, o grande tradutor Leão, o Calabrês. Ele era muito ligado a Gerberto (c. 930-1003), o futuro papa Silvestre II, quando êste ainda era arcebispo de Ravena; o curriculum vitae de Gerberto, visto do ponto de vista geográfico, é como uma síntese das estradas de Espanha e Itália: Auvergne, Catalunha, Itália do Norte (Bobbio), Reims, Itália do Norte (Ravena), Roma.

(74). - As principais etapas de Mogúncia ao Danúblo eram: Heilbronn, sôbre o Neckar, onde, desde o século IX se assinalam feiras; sôbre o Meno Francfort, que desde o século IX, também, possui um importante bairro judeu, e Würtzburgo, bispado desde o século VIII e importante mercado do século $X$, Bamberg, sôbre 0 Regnitz, não longe da sua confluência com o Meno. Pelo Rezat, afluente do Regnitz, e pelo Altmühl, afluente do Danúbio (que Carlos Magno tinha sonhado unir por um canal), desembocava-se no Danúbio, a oeste de Ratisbona.

(75). - Cf. A chegada das novas técnicas de atrelagem (a coleira de peito) pelas estradas do Este na Alta Idade Média. Lefebvre des Noëttes, L'attelage, le cheval de selle à travers les âges, Paris, 1931, pp. 121 e ss.

(76). - Ruzarii: "de Khazária "antes do que" da Rússia". Em Ratisbona, o bairro judeu se comprimia contra a abadia de Santo Emmeran. $O$ bispo de Ratisbona, Wolfgang (972-994), durante um período de fome, ordenou que os estoques de trigo fôssem vendidos pela metade do preço aos comerciantes que, vindos das regiōes as mals longínqüas, não encontravam com o que matar a fome, trigo que transportam com as suas carretas. (Vita sancti Wolfkangi, MGH, SS, IV, p. 537).

(77). - Cf. as leges portorii de 906 que se referem ao pôrto ađuaneiro de Raffelstetten $e$ indicam as atividades dos comerciantes judeus, bávaros $e$ eslavos, entregues ao comércio de escravos vindos da Boêmia e destinados à Itália, pelo passo do Brenner. (MGH, Leges, III, pp. 480 e 481). 
nhol Ibrâhîm ibn Ya'qoûb escreveu na segunda metade do século $\mathrm{X}$ :

"Praga é um grande centro de comércio; os mercadores russos e eslavos para ali vêm, procedentes de Cracóvia; do país dos Turcos (a Khazária) chegam mercadores judeus, muçulmanos e turcos com objetos de comércio e peças de ouro e êles levam escravos, peles e chumbo" (78).

Nós sabemos pela Vida de Santo Adalberto de Praga (79), que o comércio de escravos, pagãos ou cristãos, era correntemente praticado pelos mercadores judeus que os exportavam seja para o este, pela Polônia e os rios russos com destino ao Oriente muçulmano, seja para o oeste, para as encostas dos Alpes orientais, com destino à Itália ou, pelo vale do Ródano, com destino à Espanha muçulmana. De Praga, o itinerário dos judeus da Baviera continuava pelos desfiladeiros dos sudetos e pelo conjunto de planícies pantanosas e descobertas que se estendem entre o sopé norte dos Cárpatos e a margem sul da grande floresta, por Cracóvia, Przemysl, Podólia e Kiev. Kiev, a grande cidade comercial, com os seus dois bairros judeus: Shiddy, a oeste, e Khozare, a este, ligava o comércio dos judeus ocidentais ao dos orientais da Khazária, o grande estado judaico que se estendia até o mar de Azof e até o Cáspio (80). Para o sul, por Samakhars "dos judeus", no estreito de Kertch, abriase a estrada para Trebizonda e para Constantinopla; para o este, por Itil, na embocadura do Volga e pelo Cáspio, começavam as trilhas das caravanas em direção à Bagdá ou à Samarcanda. Esta rota de mercadores judeus, por detrás de Roüm já tinha sido assinalada por Ibn Khordâdhbeh, por volta de 864 (81). Às caravanas de mercadores judeus que se destinavam à Rússia dever-se-ia juntar aquêle monge irlandês que, no século $\mathrm{X}$, esmolou até Kiev (82) ou aquêle clérigo de Saint-

(78). - Ibrahim Ibn Ya'qoûb, ed. Kunik-Rosen, p. 35. Cf. C. Westberg, Ibrahim Ibn Jackub's-Reisebericht, über die Slawenlände, Mem. da Academia imp. de Ciências de São Petersburgo, 8a. série, III, 1898, p. 53 e Beiträge zur Klärung orientalischer Quellen ṫber Osteuropa, ibid., IV, 1899, pp. 211 e 275.

(79). - Vita Adalberti, MGH, SS, IV, pp. 586 e 600.

(80). - Cf. J. Brutzkus, Der Handel der Westeuropäischen Juden mit den alten Kiev, "Zeitschrift für d. Gesch. der Juden in Deutschland", t. III, 1931, pp. 97-110 e Trade with Eastern Europe, 800-1200, "Economle History Review" 1943, pp. 31-41.

(81). - BGA, VI, p. 116

(82). - Por conta da igreja de Santiago dos scotti (dos Irlandeses) em Ratisbona. 
Emmeran de Ratisbona, que morreu em Kiev (83) e cujo nome - Hartwig - as crônicas judaicas do século XI conservaram. E' o mesmo caminho que o ourives Nicolau de Verdun seguiu quando da sua viagem à Rússia.

No comêço do século XI, a estabilização e a conversão dos húngaros deveria permitir a abertura ao comércio ocidental de rotas mais cômodas, pelas planícies do Danúbio médio (84) e pelos desfiladeiros dos Cárpatos - o desfiladeiro de Doukla ou o passo de Deliatyn - em direção à Pequena Rússia e Kiev; - e também em direção ao Baixo Danúbio, os Balcans e o Império bizantino (85). Êste último itinerário foi, então, a grande rota dos peregrinos que se dirigiam à Terra Santa: itinerário seguido por Ricardo de Saint-Vanne, desde Verdun, em 10261027, por Adalberto, conde de Metz, em 1.032, por Foulque Nerra, conde de Anjou, quando do retôrno da sua terceira viagem a Jerusalém (86) e, em 1064-1065 pela grande peregrinação dirigida pelo bispo de Bamberg - Günther - peregrinação que contava entre os seus membros o arcebispo de Mogúncia e os bispos de Utrecht e Ratisbona (87); foi também a estrada seguida pelos bandos de Pedro-o-Eremita e pelo exército de Godofredo de Bouillon.

Mogúncia - e nós vimos as vias de comunicações que a ligavam estreitamente ao vale do Mosa - era o pôsto chave da linha do grande comércio que, pela Europa central e oriental se dirigia para o Oriente muçulmano e bizantino. Um viajante árabe do século X - at-Tartoushî (88) - a descreve como

(83). - Or Zaruah, I, ch. 694, p. 196 e B. Pez, Thesaurus Anedoctorum, 1721, I, p. 173, indicados por Brutzkus, loc. cit.

(84). - O rabino italiano Zedekiah ben Abraham (Ha Rofeh, cap. 60, p. 47), citado por Brutzkus (op. cit., pp. 37-38), descreve uma caravana de mercadores judeus voltando da Rússia, por volta de 1050: detidos, no dia do Sabbat, por um acidente na estrada - nas margens do Danúbio e antes do desfiladeiro de Esztergom, fazem um círculo com as suas carretas para formar uma "sala" de orações e poder, assim, celebrar as suas cerimônias rituais.

(85). - Estradas de Morávia-Vardar-Tessalônica e Morávia-Nichava-Maritza-Andrinopla-Constantinopla. Cf. C. Jirecek, Die Heerstrasse von Belgrad nach Constantinopel und die Balkanenpässe, Praga, 1877.

(86). - Ele morreu em Metz, em 1040.

(87). - Annales Altahenses majores, MGH, SS, XX, p. 815; Lambert de Hersfeld, MGH, SS, V, pp. 168-169. Para essa multidão de peregrinos (uma dezena de milhares de homens), alojamentos foram preparados em Passau, sôbre o Danúbio. Cf. P. Riant, Inventaire des lettres historiques des Croisades, "Archives de l'Orient latin", I, p. 54. Cf. também E. Joranson, The Creat German Pilgrimage of 1064-1065, in "The Crusade and other Historical Essays pr. to D. C. Munro", New York, 1928.

(88). - Originário de Tortosa no delta do Ebro. A narraçāo de sua viagem, realizada por volta de 973, é encontrada em Qazwinl, Cosmografla, ed. Wiistenfeld, Göttingen, 1848, II, p. 409. 
uma importante e opulenta cidade que se estende às margens do Reno e acrescenta:

"No mercado de Mogúncia, encontrei alguns dirhems cunhados em Samarcanda em 301 e 302 da Hégira (913915), moedas que traziam gravados o nome do príncipe e o ano da cunhagem - moedas de Nasr ibn Ahmad (89). E' de se notar encontrar-se no Extremo Ocidente, grandes quantidades de especiarias que só se produzem no Extremo Oriente: pimenta, gengibre, cravo, nardo, costus, galinga, que são exportados pela Índia".

As especiarias que tanto espanto causaram ao autor árabe ao encontrá-las no mercado da cidade renana, não eram as únicas mercadorias a circular pelas estradas do Danúbio e dos países eslavos: as tarifas aduaneirs fixando os direitos que devem pagar em certos pontos do percurso danubiano, as carretas dos ruzarii, fornecem a enumeração: importação para o Ocidente, escravos, peles, sêdas, brocados de ouro, especiarias, exportação para o Oriente, armas, metais, lãs e linhos (90). Notemos ainda que às moedas de prata do Oriente muçulmano assinaladas por al-Tartoushi se ajuntam as moedas bizantinas de ouro, que apareceram em 1024-1031 na Baviera (91).

Pelas estradas comerciais do Mosa à Boêmia, à Polônia, à Pequena Rússia, certamente muitas coisas transitaram, mas também muitas pessoas passaram por elas: no fim do século $\mathrm{X}$, os monges beneditinos, estreitamente ligados à Lorena e às regiões do Mosa, foram se estabelecer na Polônia, no nôvo estado que Boleslau-o-Forte (92) acabara de fundar. Nos começos do século XI, Ubaldo de Liège é o administrador da escola fundada perto do castelo de Praga (93). Foi em Liège que o primeiro cronista tcheco, Cosme, morto quando deão do capítulo de Praga em 1125, fêz os seus estudos: êle fala

\footnotetext{
(89). - Nasr II (913-942), quarto soberano da dinastia samânida que, de 874 a 999, governou o Irão oriental (Khorâssan), o Kharezm (ao sul do mar de Aral) e as regiōes entre o Syr e o Amou-Daria, tendo como cidades principals: Samarcanda e Boukhara. Em sua maior parte, as moedas encontradas ao longo dos rios russos e nas costas do Báltico e do mar do Norte, na Escandinávia e na Germânia, pertencem a esta dinastia (fins dos séculos IX e X).

(90). - MGH, Leges, III, pp. 480-481. 'A. Rauch, Scriptores Rerum Austriacarum, Vilna, 1794, II, p. 106:

(91). - Cf. Marc Bloch, Le problème de l'or au moyen-âge ("ÁAnnales d'histoire economique et sociale", V, 1933) cttando Bitterauf, Die Traditionen des Hochstifts Freising, II, n. 01069.

(92). - P. Francastel, op. cit., p. 104.

(93). - Anselmi Leodiensis Gesta Episcoporum Leodiensium, ap. Migne, PL, $t$. 139, col. 1094.
} 
dos jovens que deixaram a Boêmia para irem à França para se alimentarem na mesa da Dama Filosofia e que voltam fiéis à sua fresca ciência (94) .

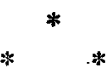

Pelas estradas, : cujo traçado conjunto esboçamos e cujo conteúdo econômico e humano dèscrevemos de maneira ainda mais breve, os ateliers mosanos receberam, nos seus inícios, o seu primeiro impulso, as suas técnicas, as suas fontes de inspiração.. Por elas, os seus produtos, as suas fórmulas artísticas, o seu gênio próprio se espalharam ao longe. As próximas comunicações estudarão numerosos aspectos dêstes problemas do ponto de vista da história da arte. Do ponto de vista da história econômica, aqui ciência auxiliar da história da arte, pode-se dizer que, por estas estradas, os ateliers mosanos receberam também matérias-primas - caras, raras e de proveniência longínqüa - necessárias a sua indústria: estanhoe cobre, ouro e prata, marfim, tintas e esmalte, pérolas e pedras preciosas. Se o estanho de Cornualha, o cobre inglês ou germânico, a prata da Frância ou da Saxe, não nos leva além do estreito círculo do Ocidente, as outras matérias-primas nos transportam aos confins do mundo de então: à Africa, ao Oceano fndico, à Asia interior, pelas grandes rotas do comércio internacional, judeu, escandinavo, italiano, bizantino, muçulmano. Suas exportações de metais, armas, peles e, sobretudo escravos, permitem ao Ocidente absorver uma parte do ouro que aflui no nôvo - e imenso - domínio econômico criado pelas. conquistas do Islão: ouro dos tesouros persas ou faraônicos, repôsto em circulação, ou da Africa austral, transportado pelos navegadores árabes e persas do Oceano fndico, ouro do Sudão sobretudo, graças ao tráfico transaariano que se organizou nos séculos VIII e IX Foi com o ouro "árabe" que se dourou o relicário de S. Vaast, em 852-853 (95) e muitas outras obras. Marfim sob a forma de tábuas (96) ou de cornos preparados para a escultura vinha ao Ocidente por intermédio de Bizâncio. Êle provinha das regiões do Oceano Indico: pequenos dentes de

(94). - Fontes Rerum Bohemicarum, II, pp. 194-195.

(95). - Sermo de relatione S. Vedasti, MGH, SS, XV, p. 402. A respeito do ouro usado na douraçã́o, cf, o édito de Pitres, de 864, em M. Prou, Monnaies carolingiennes, introd., p. 33 e nota 3 .

(96). - Menções de tabulae eburneae, mantidas em reserva nos tesouros da Igreja para serem trabalhadas no momento adeqüado. (Cf. E.Lesne, Histoire de la propriété ecclésiastique en France, IIr, p. 235). 
marfim duro da Indochina ou da fndia ou grandes dentes de marfim tenro da costa oriental da Africa (97). Até o século. XIV, com efeito, nenhuma alusão nas obras dos geógrafos árà: bes - nossa principal fonte de documentação - relativa ao marfim da Africa ocidental que, por acaso tivesse passado pelas estradas do Saara. Bizâncio, para o aprovisionamento das oficinas que trabalhavam com marfim, e que exigiam, cada vez mais, mais matéria-prima, dependia, portanto, inteiramente dos grandes mercados muçulmanos do Iraque e do Egito, onde vinha ter o marfim do Oceano Indico. De Bizâncio, uma parte era transportada pelos comerciantes italianos para as feiras de $\mathrm{Pa}$ via, de onde era redistribuído aos ateliers lotaríngios. Os navios venezianos introduziram no Ocidente as "tintas gregas $e$ indianas". As pérolas do Gôlfo Pérsico e do Mar Vermelho eram utilizadas em trabalhos de ourivesaria (98), de brocados e de agulha em relêvo, conhecido pelo nome de opus anglicarum que era uma reprodução do processo sousandijird persa das épocas sassânida e muçulmana (99). Pelo mesmo caminho eram importadas as pedras preciosas da India e do Oriente muçulmano e, entre elas, as esmeraldas do Alto Egito, das quais, uma variedade, era particularmente valorizada no Ocidente, se dermos crédito às palavras de Mas'oûdî (c. 943):

"há quatro espécies de esmeraldas: mar, a mais bela; bahrî, procuradas pelos reis dos países maritimos: India, Sind, Zandj e China; Maghrabî procuradas pelos reis do Ocidente: francos, lombardos, espanhóis, galegos, bascos, eslavos e russos; asamm, a menos bela" (100) .

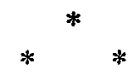

Assim, vão se precisando, pouco a pouco, as linhas de uma corrente, rêde de relações longínqüas que encerra em suas malhas tôda a Europa. Como, então, falar de um Ocidente sùbitamente transformado - por causa das conquistas islâmicas puramente terrestre, imóvel, engarrafado, tendo uma vida econômica quase fechada, onde o grande comércio estava bem mor-

\footnotetext{
(97). - Mas 'oudi, Mouroûdj adh-dhahab ("as pradarias de ouro"), ed. e trad. Barbier de Meùnard e Pavet de Courteille, Paris, 1872-1877, III, p. 8: "das regiōes dos Zandjs (a costa oriental da África) provêm êsses den. tes de elefante que pesam, cada um, mais de 150 mans (mais de 228 quilos).

(98) : - J. Seligmann, L'orfèvrerie carolingienne ("Travaux du groupe d'hist. de l'art de. la Fac. de Lettres de Paris" 1928, pp. 153 e seguintes).

(99). - J. Karabacek, Die persische Nadelmalerei :Susandschird, Leipzig, 1881.

(100). - Mourôudj, III, pp. 43 e seguintes.
} 
to (101), quando êsse Ocidente se entrega a uma vida comercial intensa? Três pequenos acontecimentos ilustram êsse grande fato: em 801 o primeiro elefante da fndia desembarca na Gália, vindo por mar, via Itália (102). Nos meados do século IX, os dromedários da Africa, enviados via Espanha, aparecem nas margens do Reno (103). Em 986, um camêlo asiático de duas corcovas, depois de percorrer as estradas da Europa oriental entra em Quedlinbourgo, Saxe (104). Rotas da Espanha, da Itália, do mundo eslavo e também dos mares nórdicos e do Atlântico, tôdas nos levam às regiões do Mosa. Elas criam aí um meio receptativo, largamente aberto às incitações mais longínqüas, meio vivo e ativo, dos mais favoráveis do aparecimento de um centro artístico. Seja grande ou pequena a parte que possamos atribuir às influências exteriores na formação da arte do Mosa, esta arte, de uma habilidade técnica suprema e de uma grande beleza plástica, não podia nascer e se desenvolver a não ser numa região de trânsito intenso. Não é uma arte de "economia fechada". Não existe, aliás, arte numa região fechada, "autárquica". A circulação ativa de homens, coisas e idéias, que abre às regiões do Mosa horizontes os mais variados e os mais longínqüos, favorece as confrontações, os progressos técnicos, o enriquecimento do repertório decorativo e iconográfico: ela permite também que os ateliers se aprovisionem fàcilmente de matérias-primas de procedência longínqüa, necessárias para as indústrias de luxo; ela torna possível, finalmente, o escoamento fácil dos produtos da arte, graças à existência de mercados de consumo suficientemente ricos e organizados (105).

(101). - Cf. as teorias de Pirenne a respeito da ecenomia da Europa entre os séculos VIII e IX, mais particularmente: Mahomet et Charlemagne, pp. 163 e 213.241.

(102). - Presente do califa de Bagdá, Harôun ar-Râshid a Carlos Magno (Annales regni Francorum, SGR, pp. 116-117). Os elefantes de Anlbal eram pequenos elefantes do Maghreb, espécie que se extinguiu antes do fim do Império romano.

(103). - Oferecidos pelo emir omiada de Córdova à Carlos-o-Calvo (Annales BerŁ́niani, SGR, p. 80). Dromedáríos provenientes da Espanha já tínham sidoo assinalados na Aquitânia merovingia, nos fins do século viI.

(104). - Enviado por Mieszko I da Polônia a Otão III (Thietmari Chronicon, SGR, p. 69). Cf. os camelos de que se serviam os mercadores roûs, nos meados do século IX, para transportar suas mercadorias das margens do Cáspio a Bagdá (Ib́n Khondadhbeh, cit. supra).

(105). - Não é inútil lembrar aqui a cunhagem de "dinheiros" ouro (valendo 12 de prata) pelos ateliers de Liége, Antuérpia e Colônia, nos séculos XI e XII. Cf. Du Cange, s. v. Denarius; Foppens, Opera diplom. et histor., Bruxelas, 1723, I, p. 176; Migne, PL, t. 179, col. 709; êstes textos foram confirmados pelo encôntro de moedas de ouro cunhadas pelo bispo Bertoldo de Utrecht (1027-1054), pelos arcebispos Herman III de Colônia (1089-1094) e Bruno de Treves (1102-1124). 
Se o esquema, em estrêla, das estradas em redor das regiões do Mosa, podem contribuir para explicar as origens da arte mosana, êle, sem dúvida, explica totalmente a difusão dessa arte nos fins do século XI e no século XII quando, então, estavam essas estradas na sua época áurea.

MAURICE LOMBARD

Directeur d'ftudes à l'feole des Hautes tudes (Sorbonne). 